U.S. Forest Service

The National forest Manual.

Instructions relating to For-

est Products. 1913 


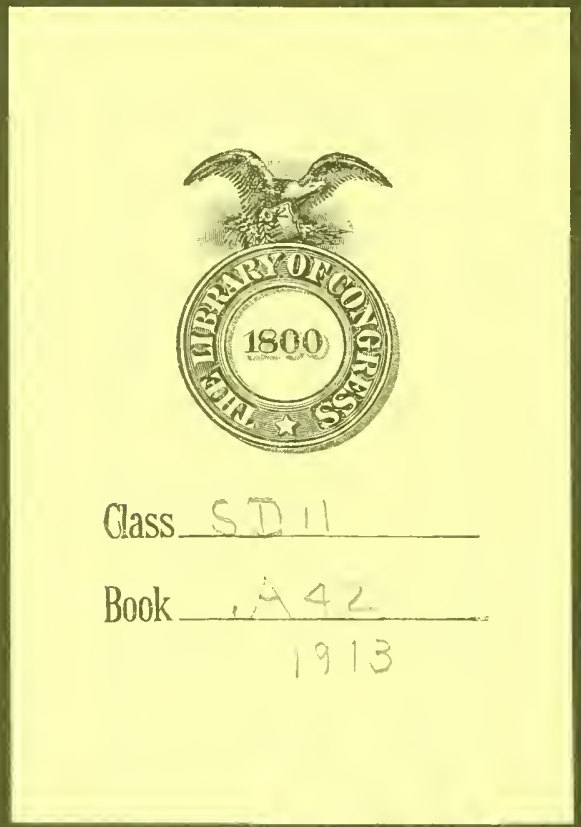


U. S. DEPARTMENT OF AGRICULTURE; FOREST SERVICE. HENRY S. GRAVES, Forester.

\section{THE NATIONAL FOREST MANUAL.}

\section{INSTRUCTIONS RELATING TO FOREST PRODUCTS.}

ISSUED BY THE

SECRETARY OF AGRICULTURE

TO TAKE EFFECT

MAY 1, 1913.

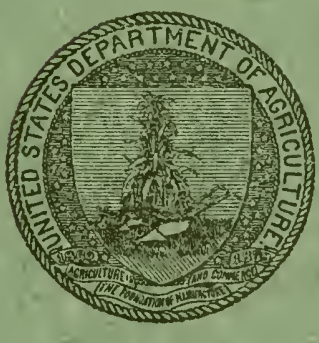

WASHINGTON:

GOVERNMENT PRINTING OFFIOE.

1913. 

U. S. DEPARTMENT OF AGRICULTURE, FOREST SERVICE. HENRY S. GRAVES, Forester.

\title{
THE NATIONAL FOREST MANUAL.
}

\author{
INSTRUCTIONS RELATING TO \\ FOREST PROUUCTS.
}

ISSUED BY THE

SECRETARY OF AGRICULTURE

TO TAKE EFFECT

MAY 1, 1913.

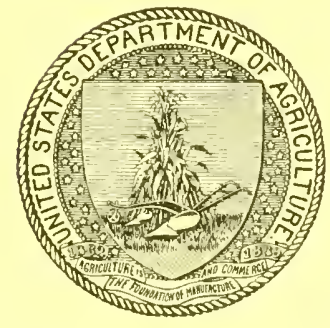

W.ISHINGTON:

GOVERNMENT PRINTING OFFICE.

1913. 


$$
\operatorname{sen}_{1} x_{x} a^{3}
$$

3. $\pi 3$.

1913

$\therefore$ 


\section{CONTENTS.}

Purpose and olganization of the IBraneh of Folest l'rofurts.

I'iage.

Field of work

Hrganization

Forest Products Iaboratory

National Folost utilizition _

Industrial Investigations _...

Stations _._...

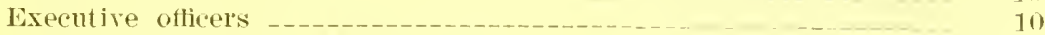

Correlation between different mits___n...

District offices and Folest I'rolucts Latholatory 11

District oflices and Imblustrial Investigations. 12

Inlustrial Investigations and Forest I'roducts Iaboratory_.

Apportionment of costs._...

riontine procednre _.....

Alministritire control _...

Correspondence _.......

Fiequests for information

General correspondence _._... 15

Laboratory corresumdence _..._.

Industrial Investimations correspondence _.......

Station correspendence

Monthly reports _._.

Strations -

District oflices _.

lolest Products Iaboriatory

Industrial Investigations -

Amual Repurts _...._.

Forest Products Laboriatory 17

District oflices _.

Files _...

(ieneral rlassification_..... 17

Filing schemes _._._.

Matters of general routine_...

Coopration with cempanies. orginizations amd individuals outside of the Forest service

Policy

Commercill afplication and cemonstration of experimentat dital is

Remmelation _..._.

l'rocedure in coopleration

Coprerative agreements _._.

I0licy _._.

Investigation of patented or proprietary alticles_...

Publication of data affecting commercial interests___ 21

Confidential information

Disposal of prints and designs

Conpilation of data from ontside sompes in Laboratory publications

Tecluical

Kiuds of investigitions

Administrative investigations

(1)

.

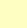

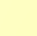

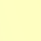


Technical procerlure-Continned. Page.

Teehuical investigations _. 23

Frudamental principles__-

Projerts _.

lucolporation in annual investigative mogram (Forest Service Order No. 41)

I'reliminary investigations _..._. 24

Working plans.

lescription of waterial

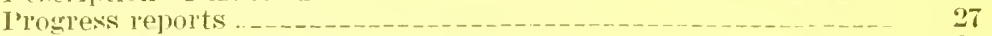

Ins]rection rejorts on furability tests_........ 27

I'priject repouts ......... 27

General inspections._. 29

By members of forest Prohuets laboratory

By members of Office of lndustrial Investigations_.......

liy member's of tistrict offices.......

Publications _._.

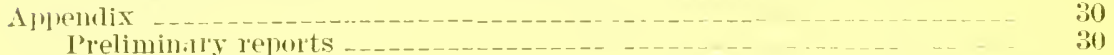

$\begin{array}{ll}\text { I'reliminaly reports } & 30 \\ \text { Working jolans } & 32\end{array}$

shipment descriptions _.

Description of samples _........ 35

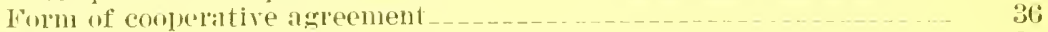

station reports. 


\title{
THE NATIONAL FOREST MANUAL.
}

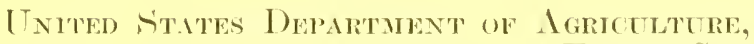 \\ Foliest Service. \\ Hashington, I). ('., 1 pril D. 3, 1913.
}

The following procedure and instructions relating to investigations in forest products are hereby established and issmed to talie effect Maly $1,191: 3$.

Approted:

H. R. ( IRINES,

B. T. Gallowar, deting serpetery.

Forester.

\section{PURPOSE AND ORGANIZATION OF THE BRANCH OF FOREST PRODUCTS.}

\section{Purpose.}

FIELD OF WORK.

The purpose of this Branch of the Forest Service is to promote the most profitable and economical ntilizition of forest products. Its work consists of:

Scope of work.

(1) Statistical and industrial studies of the production and use of wood.

(2) Experimental determination of properties, methords of treatment, and special products obtainable from woor.

(3) Application of experimental data on an industrial seale to cherk results and demon-trate their rommerial value.

(t) Promotion of ixeter utilization of products of the National Forects.

Preference to National Forest problems.

The function of the Branch is both to assist timber owners and mannfactures thronghout the Uniter states and to aid in the ad. ministration of the National Forests. Preference will be given, howerer. to investigations related directly to improved utilization and current business on the National Forests.

\section{ORGANIZATION}

Administrative head.

The administrative direction of the activities of the Branch is vester in an Issictant Forester in Washington, D. C., clesignated by the Forester.

\section{Divisions.}

The work of the Branch falls into three divisions, each uncler the supervision of the assistant forester in charge: (1) National Forest Utilization; (2) the Forest Products Laboratory; and (3) Industrial Investigations. 


\section{FOREST PRODUCTS LABORATORY.}

Purpose.

The field of the Forest Products Labolatory is to conduct technical studies and experiments designed primarily to add to the existing knowledge of the properties and constituents of wood and to develop new processes or methods of utilization having economic value. It is also the function of the Laboratory to follow up technical experiments ly the commereial application of their results, as far as may be practicalule, on an industrial soale. In general no investigation will be considered complete mutil the experimental pesults obtained at the Laboratory have been ehecked on a commercial seale and their industrial value demonstiated.

Direction of technical work.

The Laboratory directs all of the strictly technical and seientific work of the Pranch of Products within its field and the methods of experimental investigation employed. As far as practicable, technial investigations will be concentrated at the Laboratory. Where arlvisable to conduct such investigations elsewhere, this will be done: (1) loy an expert detailed from the Laboratory for the pripose and working under its immediate direction; or (2) by a local member of the servion worling under the direction of the executive officer of the mit concerned. Dnt in accoldance with plans approved by the Laboratory and such further supervision and inspection as the Direetor considers necessary. The supervision of Products experts in the National Forest distriets by the Laboratory extends only to techuical or reientific investigations conducted under the working plan procedure as defined on page 25, and is exercised through the district forester's.

Organization.

The Forest Products Laboratory is located at Madison, Mis., nnder the immediate supervision of a Dipector who reports to the assistant forester in charge of the Branch.

Administrative assistants.

Such administrative assistants as are required will be designated by the linector to assist him in supervising the work of the Laboratory and to perform special duties.

\section{Sections.}

The work of the Iaboratory is divided into sections corresponding with the major lines of investigation and desiguated by the director with the approval of the assistant forester. Each section is in charge of a section chief.

\section{Committees.}

The director of the Laboratory will designate from time to time such committees as he deems advisable to pass upon working plans for projects in particular lines of inrestigation. The aim will be to bring together in cach committere the members of the Laboratory staff whose experience and capacity in the particular line of investigation or related investigations will make their serutiny of a working plan of the enceatest valuc in acomplishing the best results under a proposed project. Sirch committers will form a permanent feature of the organization of the Forest l'roducts Laboratory, but their personnel nuy be changed from time to time as the director sees fit. 
Advisory board.

There will be associated with the Laboratory an advicory board consisting of experts of the widest possible experience and national standing in the various lines of investigation conducted at the Iaboratory and the requirements of the industries which such investigations should benefit. Arrangements will be perfected as far as possible for experts of this character to spend several weeks cach year at the Laboratory going over the plans of work, the methods employed. and the results obtained in specific projects, and advising the director and members of his stafl on any features of the work which can be improved. 'The members of the advisory board individually, will thus act as inspector's but not in any execntive capacity. The director will act upon their recommendations in so far as advisable in his judgment. Recommendations of the members of the Board which in his judgment should not be put into eflect will be submitted to the assistant forester in charge of the Branch with a statement of his riews thereon, for final decision.

Field of work.

Investigations are conducted at the Forest Products Laboratory and in cooperation with persons engaged in various wood-nsing industries, and information disseminated by publication and otherwise along the following lines:

(1) Mechanical properties of wood.

(2) Physical characteristies and properties of wood.

(3) Chemical characteristics and properties of wood.

(4) Air seasoning and artificial drying of wook.

(5) Igencies rlestructive to wood.

(6) Trood preservation.

(7) Wood distillation.

(8) Production of naval stores.

(9) Production of pulp and paper and other chemical products of wood.

\section{NATJONAL FOREST UTILIZATION.}

\section{Purpose.}

The function of experts employed in the National Forest districts is to assist and advise the district foresters on market and utilization problems involved in current. National Forest business. Investigations conducted by such experts will be restricted largely to those having a direct bearing upon administrative problems. Scientifie studies involving technical processes or experiments will ordinarily be undertaken only when necessary as part of an investigation required for administrative purposes. Other technical investigations may be undertaken in exceptional cases to assist the Forest Products Iaboratory or the Office of Industrial Investigations in their respective fields of work.

Utilization of National Forest timber.

It will be the duty of experts assigned to districts to investigate as completely as posible all utilization and market problems arising in the administration of National Forests. Such work should be conducted in cooperation with reconnaissaince parties obtaining data on stand, species, and topography, with the district engineers in secur- 
ing data on water supply and arailable power, and with any other oflicer or unit of organization in the district whose work bears on the particular investigation in hand. 'The aim of such in restigations will be: (1) to compile all published or mamscript data obtainable bearing on the problem; (2) to secure all necessary information on the physical conditions involved, as stand, species and quality of timber, a vilable water power, distance from shipping points, freight rates to most accessible malkets, and the like; and (3) to indicate what special studies of a technical or experimental nature, if any, should be unclertaken to complete the study. Such a preliminary investigation will be embodied in a report on which direct action can be taken by the district forester or assignments for further investigation made by the assistant forester in charge of the Branch.

\section{Organization.}

Products experts in the several districts are under the direction of and directly responsible to the district foresters. Their relationship to the district forester is the same as that of other members of the district oflice staff. The district forester is responsible for the assignment of such experts to the problems which they should study and for the supervision of their work. Their duties should be correlated with those of the district office of Silviculture, and where advisable such experts may, with the approval of the assistant forester in charge of Forest Products, be placed under the administrative direction of the chief of vilviculture. Their work will be under the supervision of the assistant forester in charge of the Branch, through the district forester, in the same mamner as that of district officer's assigned to Silviculture or Grazing.

\section{Field of work.}

The field of Products experts assigned to National Forest districts embraces all investigations and problems connected with the use and marketing of National Forest timber, the construction of improvements on the Forests, and related administrative questions. The following are inchuded:

(1) Studies of existing industries. covering methods and costs of manufacture, gracles or other specifications of mamactured products. and prices obtained for manufactured products. The collection of market prices, mill scale studies to determine grades and overrun, and investigations of kiln-drying methods come mnder this heading.

(2) Waste in existing industries and closer utilization possible through improved methods.

(3) New uses for National Forest species through wood preservation.

(4) Introduction of industries which will result in closer or more profitable ntilization, as the manufacture of pulp and paper, wood distillation, turpentining, and the manufacture of secondary wood products.

(5) Market prejudices against particular species or classes of material and means of orercoming them through special studies or publicity.

(6) Creneral questions of timber supply and demand, markets, and freight rates, which the district forester deems it advisable to study.

(7) Adrice and assistance in the construction of National Forest improvements, particularly in the use of rood preservatives. 
(8) Advice and assistance to persons in the respective districts, outside of the Forest Service, on any of the foregoing or related questions.

(9) Preparation of publications on any subjeets covered by the foregoing investigations which have practian or -cientific value.

(10) Demonstrations of methods or procesises developed by the Forest Service for the benefit of local industries.

Duties of forest supervisors.

To make Products work in the National Forest districts of the greatest ralue it is essential that supervisors luring to the attention of the district foresters any problems bearing on the foregoing or related subjects which exist on their Forests. The presence of large quantities of mmarketable species, of dead timber, or of material not used in current sales should be reported. Local problems in manufacture and marketing like sap stain, difliculties in kiln drying, market prejudices against usable material, and the effect of given sibicultural methods upon the average grades of lumber manufactured shonld be taken up with the l'roducts experts at the district oflice. Supervisors are expected to cooperate in studies along any of these lines and in more general inrestigations, such as local supply and demand for stumpage, which the district forester orders.

Preservative treatment of material used in improvements.

Forest supervisors should alio bring to the attention of the district foresters their needs for assistance in applying prescrative treatment to telephone poles, posts, and other material nsed in the construction of National Forest improvements. Important projects requiring snch timbers should be discussed in alvance with the Products expert in order that plans for preservative treatment may be thoronghly considered and applied if found advisable. In the discretion of the distriet forester, small treating plants may be constructed and operated on or near National Forests where of value to the Forests and the community. The object of such plants will be to facilitate National Forest improrements and to educate the people in the use of preservatives. Recommendations for their establishment should be made by supervisor's when adrisable in their judgment.

\section{INDUSTRIAL INVESTIGATIONS.}

\section{Purpose.}

The function of the Office of Industrial Investigations is to eonduct statistical and industrial studies of uses of rood in the United States. The aim of these investigations is to determine the methods and conditions under which wood is now used, the marketable products obtained from it, tendencies in methods of mamufacture, and improved methods possible particularly in the utilization of waste. When practicable such investigations will be followed by the commercial application of their results. This mit also directs all statistical investigations of the production and ne of forest products conducted by the Forest Service and standardizes the methods employed.

\section{Organization.}

Industrial Investigations is an office in the Branch of Products, under an executive officer at Washington, D. C., designated "Chief

$$
92590^{\circ}-13-2
$$


of Industrial Investigations," who reports directly to the assistant forester in charge of the Branch.

Field of work.

The work of Industrial Investigations includes the following:

(1) Collection and compilation of statistics, in cooperation with the Burean of the Census and other agencies, on the production and consumption of forest products, prevailing market and stumpage prices, imports and exports, and transportation rates.

(2) The compilation and study of specifications of rough and manufactured forest products.

(3) Studies of lumber manufacture and wood-using industries as to methods, forms of material, waste, costs, equipment, substitution of one species for another, and improvements through more conservative use of raw material.

(4) Studies of special problems or features of wood-using industries.

(5) Advice and assistance through cooperative agreements and otherwise to States, industries, and individuals concerned with such lines of work.

(6) The dissemination of results by publications.

Duties on eastern Forests.

The Office of Industrial Investigations will also assist on market and utilization problems arising in the administration of National Forests acquired in the Eastern states and conduct such special inrestigations as may be required for this purpose. Its duties in this respect ale analogons to those of Products experts in the National Forest districts.

\section{STATIONS.}

For convenience, places other than the headquarter's of the varions units of the Branch where work is to be conducted for a considerable period will be designated as "stations." Each station will be in charge of a station chief. who will be directly responsible to the executive officer of the mit to which the station reports. Stations of a permanent character will be established only with the approval of the Forester. 'Temporary stations may, howerer, be established whenever it is deemed expedient to do so by the proper executive officer.

\section{EXECUTIVE OFFICERS.}

The term "executive officer" as used in this manual means either: (1) a district forester; (2) the director of the Forest Products Laboratory; or (3) the chief of Industrial Investigations.

\section{CORRELATION BETWEEN DIFFERENT UNITS.}

Close correlation between the rarions units comprising the Branch of Products is essential to the effectiveness of the work of the Branch as a whole. The following summarizes the more important features of such correlation, 


\section{DISTRICT OFFICES AND FOREST PRODUCTS LABORATORY.}

\section{Administrative investigations.}

Investigations for administrative purposes will be initiated and directed by the district forester's. The staff of the Forest Products Laboratory will assist in such investigations which come within its field by furnishing ontlines of the information to be obtained and by personal conference with the district forester's and members of their offices, but will have no supervisory relationship to this work.

\section{Technical investigations.}

Technical investigations in the sereral districts. forming part of the annual progran, will he conducted in accordanee with working plans approved by the director of the Laboratory, when within its province. 'Their results will be reviewed by the Laboratory stati before publication. Is far as practicable such investigations will be concentrated at the Laboratory itself, but where conducted in the distriets will be under the supervision of the Laboratory stafl as defined on page 6 .

\section{Special assignments of Laboratory staff.}

Members of the Laboratory will not be assigned to special investigations in any of the districts mutil the gromind has been rovered as fully as practicable in a preliminary study by the Products expert in the district. The results of this stridy will be embodied in a preliminary report which should indicate specifically what further investigations requiring specialists from the Forest Products Laboratory should be molertaken. Requests for the assignnent of experts form the Laboratory for such investigations in the districts will be submitted to the assistant forester in charge of the Branch, with a coup of the preliminary report showing the specific problems to be solved. At the same time a copy of the report and of the letter requesting the special assignment will be sent to the director of the Laboratory who will immediately submit his recommendations and suggestions in the matter to the assistant forester. The latter will then decide whether the assignment requested should be made and send necessary instructions to the director of the Laboratory.

\section{Tests of field material.}

Material will be submitted to the Forest Products Laboratory by district foresters for special tests, and other experiments requested whenever necessary for administratire purposes and particularly for the better ntilization of National Forest timber. When such tests or experiments are not of immediate urgency, a request should be submitted to the director of the Laboratory for the incorporation of the investigations proposed in the next anmual program, unless the director finds it practicable to include the terts in current investigative projects. If the work desired by a district forester, howcrer, is of immediate urgency, the request will be submitted dirortly to the assistant forester in charge of the Branch, a copy being sent simultaneously to the director of the Forest Products Laboratory. 'The director will immediately submit to the assistant forester' his recommendations and suggestions in the matter. The latter will then decide whether the work proposed should be given preference 
orer the establisher progran of investigations at the Laboratory, and instruct the dinector and the district forester accordingly. The approved program of investigative work will not be distmibed to make tests or conduct other stndies proposed by distriet forester's which are not of direct and immediate importance in the administration of the National Forests. Urgent work of this character from the Forests will. however, with the approval of the Forester, be given precedence over the established program of the Laboratory. Material should not be shipped to the Laboratory mntil the tests desired have been approved by the director or assistant forester.

Current information and advice.

The foregoing should not be understool as limiting the fullest possible cooperation between the Forest Products Laboratory and the district foresters, in securing enrently information on specific problems, adrice, or suggestions on methods of attacking new problems.

Conferences.

To keep the Laboratory staft in touch with problems arising in the districts and to enable it to cooperate most effectively along the lines indicated, the tirector will visit the National Forest districts from time to time for conferences on the ground. Products experts assigned to districts will similarly be kept in tonch with the work of the Laboratory by occasional details. The interchange of monthly and annual reports will furnish an additional medium for keeping the Laboratory and district officers mutually informed of the work of other units.

\section{DISTRICT OFFICES AND INDUSTRIAL INVESTIGATIONS.}

\section{Working plans for industrial studies.}

Working plans for statistical studies and studies dealing with industries or species in their entirety will be approved by the Chief of Industrial Investigations. The results of such studies will be reviewed by him prior to publication. Any problems arising on National Forests whose solution will be facilitated by special studies in the east in the field of Industrial Investigations or the assignment of experts to the districts will be submitted to the assistant forester with a request for the data or other special assistance desired. The assistant forester will arrange for the investigation required as soon is practicable.

\section{Tests of material.}

Material will be submitted to the Office of Industrial Investigations by district forester's for tests by manufacturers of special products ontside of the distriet, when advisable and practicable, in accordance with plans made in advance with the chief of that office.

\section{Conferences.}

The chief of Industrial Investigations will visit the National Forest districts from time to time for conference, in order to correlate the work of his office with that of the districts as effectively as possible. 
INDUSTRIAL INVESTIGATIONS AND FOREST PRODUCTS LABORATORY.

Current information.

It is essential that the Forest Products Laboratory be kept currently in touch with the work done and results obtained by Industrial Investigations because of the close bearing of such data iipon the studies conducted at the Laboratory. 'The director of the Laboratory will designate certain of his assistants from time to time who will be responsible for the review and compilation of all data obtained on nses of wood. The chief of Industrial Investigations will send to the Laboratory for review by such designated members of the staft copies of progress reports and other current material of value to the Laboratory.

\section{Review of working plans.}

Trorking plans for new projects proposed by Industrial Investigations will be sent to the Laboratory for review and suggestions before the work is begun; and all manuscripts on indnstries, species, and other subjects will be sent to the Laboratory for review prior to their publication.

Working plans for new projects proposed at the Laboratory will be submitted to Industrial Investigations for review and sugaestions, when in the judgment of the director the work proposed has an important bearing on the field of the latter unit. Manuscripts having a sinilar bearing will be sent to Industrial Investigations for review prior to publication.

Special Laboratory tests.

The procedure outlined on page 11 for tests at the Laboratory of material sent from the districts will apply to tests and other special experiments required by Industrial Investigations in the prosecution of its studies.

\section{APPORTIONMENT OF COSTS.}

\section{Testing material.}

The cost of procuring and shipping testing material will he borne by the mit at whose instance the inrestigation was undertaken; by the Forest Products Laboratory when the material is required in connection with a Laboratory project; by Industrial In restigations when the material is required for projects assigned to that oflice; and by a National Forest district when the tests are to be made as part of at technical or administrative investigation in the district.

\section{Details.}

The cost of details of experts from the Forest Products Laboratory or Office of Industrial Investigations for assignments or conference; in the district will be borne by the unit furnishing the expert, except as other arrangenents are made in special cases by the assistant forester. 


\section{ROUTINE PROCEDURE.}

\section{ADMINISTRATIVE CONTROL.}

Action by Assistant Forester.

Action will be taken by the assistant forester in charge of the Branch on the following matters:

1. Allotments:

(1) Inmul allotment and appropriation estimates from each unit, prior to submission to the Forester.

(2) Changes in suballotments atlecting mits of the Branch or major lines of work, but not changes affecting indiridual projects or investigations.

2. Plans of work:

(1) Annual investigative program from each mit of the Branch, prior to submission to the Central Investigative Committee.

(2) New investigative projects of a technical character proposed hy any unit of the Branch during the rear. Such projects will be held for the next meeting of the Central Investigative Committee or submitted to the Forester for immediate approval, as their importance and urgency may require.

(3) Sulstitution of urent work from the field for listed inrestigative projects at the Forest Products Laboratory.

3. Per'sonnel:

(1) Appointments, separations, promotions and disciplinary action, in the case of employees taken from ciril service registers.

(2) Proposed inereases and decreases in the force employed by any unit of the Branch, including nontechnical help, for periods of 6 months or more.

(3) Assignments and transfers affecting mits or major lines of work, not individual projects.

(4) Details of experts from the Forest Products Laboratory or Oflice of Industrial Investigations for special work in the six western districts.

4. Reports:

Monthly and annual reports from all units of the Branch; special reports as requested.

5. Manuscripts of pullications, prior to submission to the Editor.

(i. Cooperative agreements involving an expenditure of over $\$ 500$ annually for the salary or expenses of members of the Service.

7. Questions of policy, changes in the Mannal and other special matter's.

Action by Branch units.

Action in all other matters will be taken by the executive officer in charge of the unit concerned, subject to the instructions contained in this Manual and to the instructions on Forest Service procedure given in the Manual on General Administration. The executive officers in charge of the Forest Products Laboratory, the Office of Tndustrial Investigations, and the respective districts will correspond directly with each other except when final action, of the claracter 
indicated above, requires the approval of the assistant forester in charge of the Branch.

\section{CORRESPONDENCE}

REQUESTS FOR INFORMATION.

Where referred.

Requests for information will be referred to the mit best equipped to furmish it, namely: (1) The Forest Products Laboratory, for data on wood properties, timber tests, preservative treatment, seasoning, pulp and paper manufacture and distillation; (2) Industrial Investigations, for data on statisties of production and on wood-nsing industries: (3) the district oflices, for data on local experiments and loeal utilization or market questions.

\section{Procedure.}

Requests for information will be acknowlerlged by the receiving oflice, by postal carcl or letter, and transmitted immediately to the proper unit of the Branch for action.

\section{GENERAL CORRESPONDENCE.}

\section{Within districts.}

Requests for information and other correspondence within a $\mathrm{Na}$ tional Forest district will as far as practicable be conducted through the district office. Exceptions to this rule in the collection of statistics or other exeneral data will be made only with the approval of the assistant forester in charge of the Branch.

\section{Outside of districts.}

Otherwise each mnit of the Branch will colrespond on matters perfaining to its field of work directly with persons or firms throughout the United States and in foreign comntries. subject to the procedure defined in the Manual on General Administration.

\section{Carbons for other units.}

Copies of correspondence bearing upon the work of another unit will in all cases be sent to such unit for its information. Carbons of letters from the Forest Products Laboratory or Office of Industrial Investigations to nembers of these mits on detail in National Forest districts, which pertain to the work of the district, will be sent to the district office.

\section{LABORATORY CORRESPONDENCE.}

The correspondence of the Forest Products Laboratory will be signed by the director. Members of the Laboratory staff other than the acting chirector may be authorized by the director to sign certain classes of correspondence when advisable in his judgment.

\section{INDUSTRIAL INVESTIGATIONS CORRESPONDENCE.}

Correspondence originating with the Office of Industrial Investigations will be siened by the chief. Nembers of the office may be authorized by the chief to sign certain classes of correspondence when advisable in his judgment. 
STITION CORRESPONDENCE.

With outside parties.

Men in charge of stations may correspond directly with ontside palties on the work of their stations. Copies of such correspondence, except that on purely rontine matters. will be forwarded to the executive officer to whom the station reports.

Copies of Service correspondence.

('opies of correspondence relating to the work of the station, originating with the assistant forester or executive officer in charge, will be formarded promptly to the station. When sueh correspondence originates with the assistant forester. copies for the station will be sent through the executive officer in charge with additional carbons for his files.

\section{MONTHLY REPORTS.}

STTATIONS.

Not later than the sth day of each month the officer in charge of each station will submit to the exeentive officer to whom he is responsible a report on the work of the previous month. This report will contain a cliscussion of the progress on all projects assigned to the station, a statistical statement, a finaneial statement and any ceneral comments necessiry. The forms to be followed in such statements are shown on pages 39 and 40 of the Appendix.

\section{DISTIRIC'T OFFICES.}

A section dealing with Fores Products will form a part of the regular monthly report from each district forester to the Forester. This section will include a discussion of the progress on all teehnical projects, listed hy title and mmber, a statement of the general or administrative investigations under way or proposed, and such comments and recommendations on the work and persomel as are neerled. ('opies of the romplete monthly report from each district will be sent to the Forest. Products Labolatory.

FOREST PRUDLC'TS I.ABOR:ATHIY.

Section reports.

Each section of the Laboratory will submit to the director not later than the sth of each month a report on the work of the previous month. 'This will include a statement of progress on all projects, a statistical statement, and any general comments necessary. The form for statistical statements is given on page 40 of the Appendix.

Laboratory report.

The reports from stations and sections will be summarized by the director for the monthly report of the Forest Products Laboratory. This report will be forwarled to the assistant forester in charge of the Branch not later than the 15 th of each month. Copies will be sent to all distriet oflices. 


\section{INDUSTRIAL INVESTIGATIONS.}

The chief of Industrial Investigations will submit to the assistant forester in charge of the Branch not later than the 5th of each month a report on the work of the previous month. 'This report will include a statement of progress on all projects and such general comments and recommendations as are necessary. Copies will be sent to the Forest Products Laboratory and to each district office.

\section{ANNUAL REPORTS.}

\section{FOREST PRODCCTS LABORATORY.}

An annual report will be submitted to the assistant forester by the director of the Forest Products Laboratory not later than $\mathrm{J}_{11} \dot{l}_{\mathrm{y}} 15$ of each year. This report will review the work of the Laboratory during the past fical year, discussing particnlarly broad questions of organization, policy and lines of work rather than detailed inves. tigations.

\section{DISTRICT OFFICES.}

The work in Forest Products will be discussed in the nonstatistical annual report of each district forester. Copies of such reports will be sent to the Forest Products Laboratory.

\section{FILES.}

GENERAI, CLASSIFICATION.

The files of the Branch will contain records of four general classes: Test records.

(1) Test records, including all experimental data not yet analyzed or put in final form. Such records will be filed at the Forest Prod. net $\rightarrow$ Laboratory in the section of computing. They will be classified. by shipment and filed by project number as far as possible.

Project records.

(2) Reports, papers and correspondence relating to specific projects. This class includes all project records not coming under Class 1, namely: Preliminary reports, cooperative agreements, working plans, progress reports, inspection reports and project reports, together with all correspondence related to them. Snch records will be classified by projects and filed by project numbers. Shipment descriptions will be filed serially by shipment numbers.

Classified information.

(3) Information not secured in connection with a project. This includes all data not contained in Classes 1 and 2 and which giri not be classified by project; information not forming an essential part of the project records; and information secured in project investigations, classified by subjects. This file should include a duplicate copy of final project reports and a classified index to the project fils.

$$
92590^{\circ}-13-3
$$


Correspondence.

(4) Correspondence of a supervisory character related to projects will be filed by project number. Correspondence containing important data not related to a particular project will be filed under Study numbers. Other correspondence will be filed alphabetically.

FIIING SCIIEMES.

Filing schemes conforming with the foregoing classification and with the general rules preseribed by the Forester will be employed by the executive officer in charge of each unit of the Branch. The files of Industrial Investigations will include correspondence on all matters handled by the assistant forester in charge of the Branch except special recoids of a confidential character, which will be kept in his own office.

MATTERS OF GENERAL ROUTINE.

The instructions contained in the Manual of General Administration and Protection on matters of general routine, not covered specifically in this Manual, will govern members and units of the Branch of Forest Products.

\section{COOPERATION WITH COMPANIES, ORGANIZATIONS AND INDI- VIDUALS OUTSIDE OF THE FOREST SERVICE.}

\section{POLICY.}

It is the policy of the Forest Service to secure to as large an extent as practicable the cooperation of the wood-using industries most directly concerned with the subjects or problems under investigation. The desirability of cooperation and its exact terms will be determined in each specific case, in accordance with the following general policy and procedure:

\section{POLICY IN COOPERATION.}

COMMERCIAL APPLICATION AND DEMONSTRATION OF EXPERIMENTAL DATA.

Check on commercial scale necessary.

As a general rule, no investigation conducted by the Branch of Products will be regarded as complete until the results obtained experimentally have been checked on a commercial scale and their industrial application determined. This will ordinarily be accomplished through cooperation with individuals or companies using wood and who are commercially interested in the possibilities of the processes or articles in question.

Repeated cooperation covering same ground inadvisable.

After experimental results have been satisfactorily checked on a commercial scale and their applicability to wood-using industries demonstrated, further cooperation covering the same ground will not be entered into. This course is essential to restrict the activities of the Branch to the determination of improved methods of using wood and to avoid the danger of becoming consulting experts for private interests. 
Cooperation in construction of commercial plants.

The design, construction and operation of commercial plants for wood preservation, distillation, kiln-drying, and similar work may be undertaken in exceptional cases, when a new process will be denonstrated and the plant used, at least in part, for experimental work from which the service will derive needed information. If new information will not be gained by the Service from the operation of such a plant, or new processes not yet commercially established are not to be demonstrated, the cooperation should not be mndertaken. The information of the Service on such plants, including designs and specifications, should, however, be made available to anyone interested. The Service may also indicate the approximate cost of the construction and operation of such plants and submit suggestions on the plans and specifications if desired. Under such circumstances, however, applicants should be referred to consulting engineers, the Service furnishing only such general advice and assistance as can be given at slight cost.

Inspection of plants or processes.

The Service may on request examine the methods of individuals or companies in handling forest products and prepare plans for improving such methods, provided that the purpose is primarily to reduce waste and to obtain information of general value to the industries concerned. If no new information will probably be obtained, such work should not be undertaken but the applicant referred to a consulting expert.

\section{REMUNERATION.}

Salary and expenses of Forest officers.

In cases of active cooperation, there should be a remuneration to the Service equivalent to the total cost of the work done for the cooperator, including both the time and expense of the members of the Service detailed to the project. Such remuneration may be reduced by the extent to which the work is strictly experimental and of value chiefly to the Service rather than to the cooperator. When practically all of the work proposed is investigative, the Service having little or no expert knowledge on the subject to begin with, and the results will be of value chiefly to the general public, the charge to the applicant may be made comparatively low or eliminated altogether.

Furnishing material.

Whenever practicable, arrangements will be made with cooperators or others especially interested in the investigation to furnish all of the material necessary for the work.

\section{PROCEDURE IN COOPERATION.}

COOPERATIVE AGREEMENTS.

Written agreements covering cooperation.

As far as practicable, cooperative projects will be covered by written agreements. Such agreements are required whenever cooperative investigations of a specific character are to be continued for a period of six months or longer; or when the total expenditure of the 
Forest Service on the work proposed will exceed $\$ 100$. Cooperative agreements shonld state clearly "the work to be done and the terms for doing it agreed upon by the Service and the cooperator. They will bear the same title and number as the projects in connection with which the cooperation is entered into. The form and general terms of cooperative agreements, with a discussion of their use, are given on pages 36 to 39 of the Appendix.

Preparation of agreements.

The preparation of a cooperative agreement will be authorized in ach instance by the execntive officer in charge of the unit of the Branch in question. In no case will any subordinate member of the organization obligate the Service to undertake cooperation without the specific approval in adrance of the executive officer to whom he is responsible.

Approval of agreements.

Cooperative agreements with individuals, companies or corporations involving the expenditure of not more than $\$ 500$ anmully in the time and expenses of members of the Service, whether from Service funds or from funds to be deposited by the cooperator, will be approved by the execntive ofticer in charge of the mnit of the Branch concerned. Agreements with individuals or companies involving an annual expenditure of more than $\$, 500$ and agreements with other bureaus of the Federal Government will be approved by the Forester. Agreements with States and with other departments of the Federal Government will be approved by the Secretary of Agri"ulture.

Summary of procedure.

The procedure in cooperative agreements is as follows:

(1) Agreement authorized by executive officer in charge of the unit.

(2) Agreement prepared by member of the Service conducting the project and executed by the cooperator.

(3) Agreement approved by execntive officer in charge of the mit, if within his anthority; otherwise initialed by him and submitted to the Assistant Forester, who will initial the agreement if it meets with his approval and submit it to the Forester.

(4) Copies of approved agreement filed: (a) With cooperator; (b) at the office in charge of the project: (c) at the Washington office in the case of agreements approved by the Forester or Secretary.

\section{POLICY.}

The following discussion of questions of policy are for the guidance of member's of the Branch of Products in dealing with specific cases:

\section{INVESTIGATION OF PATENTED OR PROPRIETARY ARTICLES.}

Undertaken only when of general value.

Investigations of patented or proprietary articles, materials or processes will be undertaken only when the data sought are needled by the Service or will be of general public benefit. Such investigations will not be undertaken solely for the information or benefit of 
the individual or company interested. If such studies are undertaken, it is immaterial whether the company or individual is a cooperator in the work. The essential thing is that the Service obtain the best conditions for a successful investigation. In no case will a charge be made by the Service for such work but the individual or company interested may furnish without charge materials or facilities for the inrestigation.

\section{PUBLICATION OF DATA AFFECTING COMIMERCIAL INTERESTS.}

The Forest Service will not hesitate to publish the results of scientific investigations, when conclusively established, regardless of the effect of such publication, either beneficial or detrimental, upon com mercial interests engaged in exploiting the articles or processes inrestigated. It is, however, essential that such publications be restricted to data which have been scientifically determined beyond possibility of error. This will ordinarily require publishing information only which has been obtained by the Forest service itself. Information from other sources should be included in publications: affecting existing commercial interests only when its authenticity is as certain as if it had been obtained by the Forest Service in the first instance.

Use of proprietary names.

The names of patented or proprietary processes and articles may be used in such publications, preceded by a qualifying phrase such as "Preservatives sold as." No statement other than a mere presentation of the faets should be published which could be construed as an endorsement by the Forest Service of any commercial article or process.

\section{CONFIDENTIAL INFORMATION.}

Members of the Forest Service may and should receive confidential information. Assurance may be given that such information will not be used in any way which would make public the operations of an individual plant or the details of the business of any specific operator. No guarantee to this effect, however. can be given other than the good faith and honesty of the officer who receires the information.

\section{DISPOSAL OF PRINTS AND DESIGNS.}

Photographic prints, blue prints, sketches and designs may be sold at cost with 10 per cent additional (act of March 4, 1907), with the approval of the Forester: or given without charge to cooperators and in other cases where valuable edncational results will be obtained. See Manual on General Administration and Protection, page 5r.

\section{COMPILATION OF DATA FROM OUTSIDE SOURCES IN LABORATORY PUBLICATIONS.}

The greater part of the material prepared for publication at the Forest Products Laboratory will be original data experimentally established at the Laboratory itself. Publications of such data, however, should include references to similar or related data obtained elsewhere as far as necessary to make the publication of the maximm value to those interested in the subject with which the publication 
deals. The reference to such ontside data may be restricted to a brief summary and bibliography, or discussed in as much detail as the specific publication requires. Outside data must be used with great caution in publications affecting existing commercial interests and limited only to such as have been established with absolute certainty. Subject to this limitation, it will be the policy of the Laboratory to include such other material in addition to that obtained by its own staff as will make its publications of the greatest value to the readers.

The same policy will be followed in the preparation of publications by other units of the Branch.

\section{TECHNICAL PROCEDURE.}

\section{KINDS OF INVESTIGATIONS.}

Investigations relating to Forest Products will be classed as administrative investigations and technical investigations. Administrative investigations are undertaken primarily to assist the administration of the National Forests. They seek specific information for local administrative needs. They do not require technical experiments or processes. They consist usually in the study of existing industries or methods and compilation of existing data. Technical investigations, while often undertaken to secure information needed in the administration of National Forests, require, as a rule, technical processes or experiments. They aim to develop new scientific principles or facts of broad application, or to assemble data for publication.

\section{ADMINISTRATIVE INVESTIGATIONS.}

Under control of district foresters.

Administrative investigations may be undertaken by district foresters whenever necessary in their judgment and conducted under their instructions in the manner best calculated to accomplish the objects sought. As far as practicable, such investigations should be included in the annual program submitted to the Central Investigative Committee, to keep the central committee and the Forester informed of proposed work and afford opportunity for criticism and suggestion. Administrative investigations should be conducted as far as practicable in accordance with the principles defined below which govern technical investigations. They will not, however, be subject to the technical procedure outlined hereafter. They will be listed by the central committee separately from the technical investigations. Furthermore, the district foresters will not be restricted by such lists but may initiate additional investigations of this character at any time during the year when need of them exists.

Relation to technical investigations.

When an investigation is undertaken for administrative purposes but involves technical processes or experiments, it will be classed as a technical investigation. Similarly, when an administrative investigation indicates the need of technical experiments, before all the data Aesired can be obtained, a technical investigative project should be proposed by the district forester. Such projects will be subject to the following technical procedure: 
TECHNICAL INVESTIGATIONS.

FUNDAMENTAL PRINCIPLES.

In conducting technical inrestigations it is necessary :

(1) That the importance of the results sought be carefully weighed in comparison with other work proposed by the varions units of the Forest Service, and that the work be correlated as far as practicable with any other investigations in the same or related fields.

(2) That the investigator have a clear conception of the purpose and value of the investigation and of the methods to be followed in conducting it, and that the purpose and methods be made matters of record.

(3) That the plan for conducting the investigation be perfected as far as possible before work is begum.

(4) That complete information on materials used be secured and recorded.

(5) That standard methods and terms be used as far as possible to coordinate the work of the entire Branch.

(6) That frequent partial summaries and analyses of results be made so that plans or methods may be modified as found necessary before the work has proceeded too far.

(7) That complete final summaries and analyses of results be embodied in a written report of permanent record.

The following procedure is established to meet these requirements:

\section{PROJECTS.}

The project is the unit for conducting technical investigations. It may consist of a series of tests or experiments conducted:

(1) For experimental research to develop new facts.

(2) For verification of experimental results on a commercial scale.

(3) For cooperation with ontside parties in the application of scientific principles and processes developed by research in order to demonstrate their commercial value.

(4) For the collection of statistics and information pertaining to wood-using industries, waste, substitutes, etc., of a specialized and intensive character.

Projects may be conducted independently or in cooperation with individuals, states, or commercial organizations.

Designation of projects.

Every project will be assigned a number by the director of the Forest Products Laboratory or the chief of Industrial Investigations. As far as practicable, the project title and number will be assigned when it is decided to undertake the specific investigation. When a preliminary investigation is necessary to determine the advisability of the project, a number will not be assigned until the preliminary report has been made and approved.

\section{Steps in projects.}

Projects, as a rule, involve the following steps. certain of which may be eliminated in specific cases:

(1) Incorporation in annual investigative program.

(2) Preliminary investigation. 
(3) Working plan.

(4) Description of materials.

(5) Progress reports.

(6) Inspection reports.

(7) Project report, which may or may not be published.

Where cooperation with ontside parties is involved, a written cooperative agreement will ordinarily be prepared and executed, following the preliminary investigation.

IXCORPORATION IN ANNLAL INVESTIGATIVE PROGRAM (FOREST SERVICE ORDER NO. 41).

Review by offices and committees.

Every proposed technical investigation will be submitted to the district investigative committee, if in a district; or to the members of the Service designated by the director of the Forest Products Laboratory or the chief of Industrial Investigations, as the case may be, to pass upon proposed investigations and make up an annual program for the mit of the Branch in question. The program of technical investigations for each mit, after approval by the executive officer in charge, will be submitted directly to the assistant forester in charge of the Branch. The assistant forester, in consultation with the director of the Forest Products Laboratory and the chief of Industrial Investigations, will thereupon make up an investigative program for the Brancl of Products for submission to the Central Investigative Committee. After the annual investigative program of the Forest Service has been approved by the central committee and the Forester, the assistant forester will instruct each of the executive officers in the Branch as to the projects assigned to his unit for the ensuing year.

\section{PRELIMIARY INVESTIGATIONS.}

Purpose.

A preliminary investigation may be made to determine the advisability of a proposed project or to secure information upon which to base a working plan. Reports on prelininary investigations are termed "Preliminary reports." Suggestive outlines for such reports are given on pages 30 to 32 of the Ippendix.

Summary of procedure.

The procedure followed in preliminary investigations and reports is as follows:

(1) Investigation ordered by the director of the Forest Product Laboratory, the chief of Industrial Investigations, or a district forester.

(2) Report prepared and signed by the member of the Service making the investigation.

(3) Report approved and initialed by the executive officer authorizing the investigation.

(1) Two copies of the report submitter to the director of the Forest Products Laboratory if the project is within the province of the Laboratory, or to the chief of Industrial Investigations if the project is within the field of that office.

(5) One copy of the report returned by the director or chief with comments and a statement of action required. 


\section{Importance.}

\section{WORKING PLANS.}

The success of a technical investigation is often determined by the care exercised in planning the details of the work. Work under a project will not begin until a plan has been prepared by the member of the Service assigned to the investigation and approved by the proper officers. If a detailed plan can not be made at the outset, an outline describing the essential features of the inrestigation will be prepared and approved. Such outlines will be termed "Preliminary plans".

\section{Scope.}

As far as possible working plans will contain detailed instructions for collecting material and conducting the investigation. The discusision under each topic should be full and accompanied by any sketches or drawings which will assist in making the ideas of the writer clear and specific.

\section{Designation.}

Working plans will be given the title and number of the project under which they are prepared. When a working plan covers only a part of a proposed project, successive plans will be prepared and designated numerically (as Part 1, Part 2, ete.). When a working plan is revised, the revision will be designated alphabetically, as Torking Plan 100\%.

\section{Approval.}

Unless otherwise specified in the instructions transmitting the annual program of investigative work to each unit of the Branch, all working plans for technieal investigations will be approved by the director of the Forest Products Laboratory or the chief of Industrial Investigations, in accordance with the nature of the investigation. In specific cases, designated in the instructions of the assistant forester, working plans will be submitted to him for approval.

\section{Review by officers and committees.}

I hefore any working plan is approved, the executive officer will obtain the judgment of the members of the Branch or of other branches who are most experienced in the kind of investigation proposed or otherwise best qualified to act, on the completeness of the plan, the choice of methods and materials to be used, the accuracy of the data to be obtained and any other features of the plan which affect the value of the entire inrestigation. At the Forest Products Laboratory every working plan will be submitted to a committee of experts designated by the director to pass rpon all plans within specified fickls of investigation. The judgment of any other members of the liranch wherever employed who are qualified for any particular rea: on to pass upon certain features of the work will also be obtained. Working plans for projects under Industrial Investigations will be submitted to the Forest Products Laboratory for comment and criticism before they are approved by the chief of office. Working plans prepared at the Laboratory which involve problems in the field of Industrial Investigations will be submitted to the chief of that office for review hefore they are approved. Plans which have a bearing upon the work of other branches will be referred to them for eriticism and suggestions hefore final approral. It is essential that the judgment of any members of the Service whose opinion 
would be of value in a specific investigation be secured before the working plan is approved by the executive officer.

Procedure with modifications.

Modifications of approved working plans will follow the same procedure as the original plan.

Working plan outlines.

A suggested outline for use in the preparation of working plans is given on pages 32 and 33 of the Appendix.

Summary of procedure.

The procedure followed in working plans is summarized as follows:

(1) Prepared and signed by a member of the Service assigned to conduct the project.

(2) Initialed by district forester or other executive officer supervising the work.

(3) Reviewed by committtee of experts on work of the general character involved or related lines of work and by others whose judgment on the plan should be obtained.

(4) Reviewed by executive officers of other units of the Branch or of other branches.

(5) Approved by the director of the Forest Products Laboratory or chief of Industrial Investigations, in the case of plans within the respective provinces of each, or by the assistant forester in charge of the Branch when so directed.

(6) Filed at: (a) Office of final approval (Forest Products Laboratory or Industrial Investigations); (b) offices executing the work.

\section{DESCRIPTION OF MATERIAI.}

Material received for experimental purposes will be classified as "shipments" or "samples."

Shipment.

A shipment consists of a quantity of material handled as a unit before reaching a station, such as consignments of creosote, timbers for testing, material for pulpwood experiments and bulky chemicals. A shipment may be received in one or more installments. but different installments must have the same general history and characteristic properties. Each shipment will be given a symbol consisting of a letter indicating the receiving station and a serial number. For example, the first shipment received at the Forest Products Laboratory is designated "Shipment $\mathrm{L}-1$ "; the second shipment, "Shipment $\mathrm{L}-2 "$, etc.

Shipment descriptions.

Shipments will be lescribed in accordance with the instructions on pages 32 to 35 of the Appendix. The procedure in shipment descriptions is as follows:

(1) Prepared and signed jointly by persons collecting and receiving the material.

(2) Filed at: (a) Laboratory or Office of Industrial Investigations, as the case may be; $(b)$ office or station supervising the work. Sample.

Samples are relatively small quantities of material for chemical analysis or other technical examination. A sample may consist of a 
representative part of a shipment. of a product of experimental work, or other material which requires examination. Samples will be collected in accordance with standard instructions, described by the transmitting oflicer. and lesignated at the receiving station. i sample designation consists of a letter indicating the class in which it belongs and a serial number. Instructions for collecting and describing samples are given on pages 35 and 36 of the Appendix.

Nature.

ProgiRESS REPOR'IS.

From time to time as work on a project progresses, reports on the results secured will be prepared. These are "progress reports", bearing the title and number of the project. 'The procedure to be followed in such reports is as follows:

Summary of procedure.

(1) Prepared when called for by the executive officer in charge of the work.

(2) Approved by the executive officer in charge.

(3) Copies sent to oflices which should be informed of its development.

(4) Filed at: (a) Office supervising the work; (b) Forest Products Laboratory or Oflice of Industrial Investigations, as the case may be.

(5) Summary of information sent to cooperators, if a cooperative project.

\section{Purpose.}

INSPECTION REPORTS ON DURABILITY TESTS.

In projects where material is placed in actual service to test its efficiency, inspections are required from time to time. Reports on such inspections will be designated "Inspection reports" (1, 2. etc.), bearing the title and number of the projeet. Outlines for such reports will be furnished by the director of the Forest Products I aboratory on request from the executive office in charge of any unit of the Branch.

Summary of procedure.

The procedure followed in inspection reports is as follows:

(1) Prepared and signed by person making the inspection.

(2) Initialed by executive officer in cliarge of the work.

(3) Approved by the director of the Laboratory.

(4) Filed at: $(a)$ Executive office in immediate charge of the work; (b) the Forest Products Laboratory; (c) other offices which should be kept informed of the progress of the test.

(5) Copies sent to cooperators, if a cooperative project.

\section{Nature.}

I'ROJECT REPORTS.

A project report is prepared at the completion of each technical investigation. It slould contain any photographs, drawings, diagrams. tables. ete. required to present the results in the most satisfactory way, together with a full discussion of the work from the beginning of the project to its completion. If all data obtained are not. included in the report, it should contain a complete list of the data records secured. 
Summary of procedure.

The following procedure will be followed in project reports:

(1) Prepared and signed by the member of the Service conducting the project.

(2) Initialed by execntive oflicer in immediate charge of the work.

(3) Approved by the director of the Laboratory or chief of Industrial Investigations, and other work which should be done in the nature of further investigation, commercial demonstration, etc., indicated.

(t) Filed at: (a) Execntive oflice in immediate charge of the work: (b) Forest Products Laboratory or Office of Industrial Investigations in projects within the respective provinces of each, including original drawings, tables and other data: $(c)$ other offices or branches interested in the project; (d) Forest Service library.

(5) Revised copy sent to cooperators, if a cooperative project.

\section{GENERAI INSPECTIONS.}

Inspections of plans, commercial processes, etc., will be made when autborized by an executive ofticer. 'The procedure in such inspections is as follows:

\section{BY MEMBERS OF FOREST PRODUCTS IABORATORY.}

(1) Inspections will be marle when anthorized by the director.

(2) Reports will be prepared in accordance with suggestive outlines approved by the director.

(3) Reports will be filed at: (a) The Forest Products Laboratory; (b) the Office of Industrial Investigations; (c) the district and Chieago oflices if of value in their work.

BY MEMBERS OF OFFICE OF INDTSTRIAL INVESTIGATIONS.

(1) Inspections will be made when authorized by the chief of office.

(2) Reports will be prepared in accordance with outlines approved by the chief of Industrial Investigations, signed by the person making the inspection and approved by the chief of the office.

(3) Reports will be filed at: (a) The Office of Industrial Tnvestigations; ( $)$ ) the Forest Products Laboratory; $(c)$ the district and Chicago oflices if of value in their work.

BY MEMIBERS OF DISTRICT OFFICES.

(1) Inspection will be made when authorized by the district forester.

(2) Suggestive outlines for inspection reports will be furnished on request by the director of the Forest Products Laboratory or chief of Industrial Investigations.

(3) Reports will be signed by the person making the inspection and approved by the district forester or an assistant district forester to whom anthority maty be delegated by the district forester.

(4) Reports will be filed at: (a) District office; (b) Forest Products Laboratory; $(c)$ Office of Industrial Investigations. 


\section{PUBLICATIONS.}

\section{Assignments.}

Assignments for the preparation of publications will be made by the executive officer in charge of each unit in accordance with the approved investigative programs and the instructions of the assistant forester. Authors will prepare outlines and synopses of proposed manuscripts which they will submit to the executive oflicer in charge of their work for approval, and to such other units or branches as he may deem advisable for criticism or suggestions.

Approval of manuscripts and addresses.

Manuscripts prepared for publication by the department or elsewhere or for delivery at public meetings will be submitted to the executive officer in charge for approval before publication or delivery. The publication of articles will be further subject to the general procedure established by the Secretary or Forester. 


\section{APPENDIX.}

\section{PRELIMINARY REPORTS.}

Preliminary reports rary greatly in different projects, but in general are of two classes:

(1) Those summarizing existing knowledge on a given subject.

(2) Those discussing conditions at a particular plant or place at which it is proposerl to conduct a project.

In every case an outline for the preliminary report must be aproved by the execntive officer before an investigation is begun. The following outlines are suggestive only, and may be modified as requiled for adaptation to specific projects.

Form of title-page.

INited States Imepartalent of Agriculture.

Forest Service.

Forest Iroducts Laboratory.

DISTR1CT --

OR

OfFICE OF INDUSTRIAL INVESTIGations.

Project No.

('Title of project.)

PRELIMINARY REPORT.

(Signed)

(Title.)

Aproved :

(Date.)

(Title.)

30

(Date.) 
For General Investigations.

ProJect No. -..-

Title:

Preliminary report.

1. Purpose.

a. Need of work.

b. Anticipated results.

2. Previous work.

1. Forest Service.

a. Date, place, and auspices under which work was done. (Give especial attention to factors influencing quality of work.)

b. Apparatus and methods employed.

c. Results.

d. Criticisms and conclusions.

2. Other investigations.

a. Dite, place, and auspices under which work was done. (Give especial attention to factors influencing quality of work.)

b. Apparatus and methods employed.

c. Results.

d. Criticisms and conclusions.

3. Bibliography.

4. Recommendations, with reasons.

5. Estimates.

a. Time required.

b. Cost.

1. Salaries.

2. Equipment.

3. Material.

For investigations of plants or processes.

Project No.

Title:

Preliminary report.

1. Purpose.

a. Need of work.

b. Anticipated results.

2. Business organization.
a. Nime of operator and owner.
b. Location of administrative offices.
c. Representative dealt with.

3. Patents, franchises, concessions.

4. Raw materials.
a. Kind (species, form, condition).
b. Source.
c. Amount.
d. Cost f. o. b. plant

5. Plant

a. Any points of interest about its history.

b. Layout. It is desirable to have this section of the report accompanied by sketches or drawings, as follows:

1. General plan of plant, showing yards, general arrangement of buildings, ete.

2. Plan of plant proper, showing general arrangement of apparatus.

6. Apparatus. (Standard equipment may be deseribed by trade designations. Special equipment in handling. working, or treating wood should be described in detail. Whenever possible the verbal description should be supplemented by sketches showing the pertinent details of the apparatus. In some cases information on power, light, heat, water supply, ventilation, fire protection, etc., may also be desired.) 
7. Processes.

All processes of handling. treating, or working wood should be described in detail. Regin with the material as received and describe successively the different stages of manufacture or treatment. The description should be divided accolding to the following or some other convenient form, the cost of each step being discusserl:

1. Preliminary handling and treatment.

2. Conversion process.

3. Finishing process.

S. Products and by-ploducts.

1. Kinds.

2. Amounts.

3. Inslection and grading.

4. Selling prices.

5. Uses.

9. Waste products.

1. Kinds.

2. Amounts.

3. Attempted and possible uses.

10. Renarlis and recommendations.

11. Estimates.

\section{WORKING PLANS.}

Form of title-page.

United States Departaen of Agriculture.

Forest Service.

Forest I'roducts LABoratory.

DISTRICT --

OR

Office of Industrial Investigations.

Project No.

(Title of project.)

WORKING PLAN NO. -...

(Signel)

(Title.)

(Date.)

Approved :

(Title.)

(Date.)

NoTE.-If the project is conducted at a permanent station. put the name of the station on the title-page. 
Outline of plan.

Project No. Title:

Working Plan No.

(1) Purpose of nork.

('This parascaply should state elearly and fully just what the work is expecterl to accomplish.)

(2) Detailed list of materials needed and instructions for their collection.

(3) Detalesl instructions for carrying on work.

a. Concise statement giving the method of grouning and marking material. The srstem used will be standard, but just what will constitute a "slijmment," " prece." "stick," etc. sinould be clearly stated.

b. Description of nsethods of testing or treating. Each chemical or preservative treatment or method of testing, soaking, seasoning. etc. not standardized. should be briefly but fully described. Standand methous will be described by reference to laboratory instructions or other anthorities. The character to be used in the "matks" of a specimen to indicate the treatment to which is has been subjected, shomld also be detined.

$c$. I escription of all special methorls of keening records. both before and after test.

1. Moisture and similar test deteminations to be made.

e. Photograluhs, sketches, and drawings.

f. Final disposition of material.

(4) Future inspection or treatment of material.

\section{SHIPIMENT DESCRIPTIONS.}

The following terms will he used in marking and describing shipments:

Piece.

A piece is the first sublivision of a shipment which it is desimble to regard as a mint. It may he a log. a stringer, a strip from which small specimens are to he taken, a wagom axle, a bale of frejglit, etc. The pieces comprosing al shipment will he numbered serjally. The piece mmber will consist of the numler of the shimment and the serial number of the liece. For example, the numbers of piecess in shipment 10 would be $10-1,10-2$, ete.

\section{Stick.}

The term stick is applied to specimens serured from the first suldivision of a liece. I stick number will consist of the number of the piece from which it is cut and a serial number. For eximlule, sticks secured from piece No. 10-1 will be numbered 10-1-1, 10-1-2, ete.

\section{Mark.}

A mark consists of one or more chalacters sjgufyng factors which are to be considered in analyzing the test data. Arabic numerals in a mark signify that the specimen was serulerl from a stirk. letters, lioman mumerals, am other characters may be embolied in a malk to designate methods of drymg, treating, position in the tree, etc. whes it is desilable to make a recold of such factors.

The information required on material used in expejiments may be divided into the following generall classes.

\section{No. 1. Field notes.}

All material usal in research work will generally be collected bs a represontative of the Forest service, who will serule such information on its origin as may he indicated in the working plan. When the materjal collected is worl, the field notes will be entered on simple form a. For material other llan wood, the information desired will be sprecified in the worling plan. The collector will classify the material collected into shipments, pieces, sticlis. etc. in acerrance with the dilections contained in the working filan, and use these designations in the prejuration of lis notes. Tuless the collector is al)solutely smo of the identily of the specinems lie should not make collections. 
Form for field notes.

Sample form $n$.

\section{United śtates Departalent of Agriculture.}

Folist SERVICE.

Iroject No.

shimment arseriptions-Fichd notes.

Tree number _..---_; Species

Locality cut: State rut ; Collnty ; Township ip.--noctite Absolute elevation

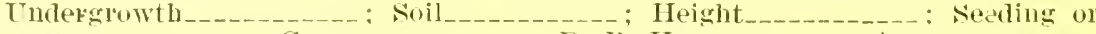

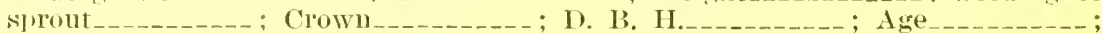
Stem_______; Date silwed________; IIow and when transported from woods

List of specimens saued.

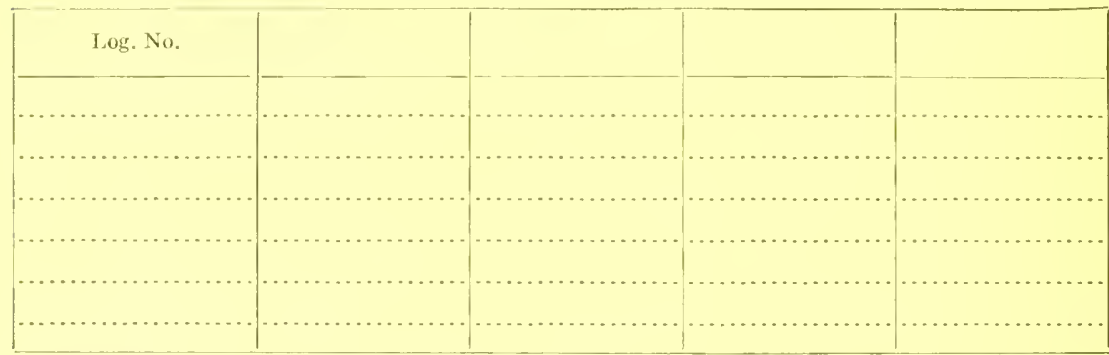

Rentirks:

No. 2. Notes on Manufacturing and Shipping.

The notes on maufacture and shipment called for in simple form $b$, which is aplenter, will also be made by the collector of the material.

As soon as the material is shipled, the collectol will forward by registered mail duplicate copies of his notes entered on sample forms a and $b$ to the man in charge of the station to which the matelial is shipped.

Form for notes on manufacturing and shipping.

sample form $b$.

United states Departuent of Agriculture.

Forest service.

Iroject No.

Shipment

SHIPMENT DESCRIPTION.

Notes on manufactming and shipping.

Bill of material composing shipment

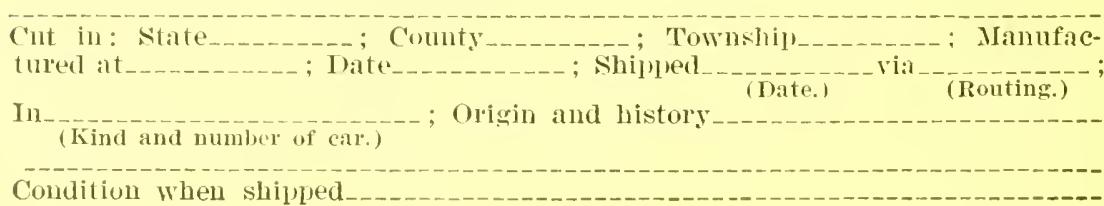


No. 3. Notes on condition and disposition of material when received at destination.

These notes will be entered los the man in charge of the station on sample form $c$. He will then transmit to the executive ofticer in charge a coly of these notes, as well as a coly of the motes transmitted in him by the collector of the material. Sample form $c$ is als follows:

Form for notes at receiving station.

Sample form $c$.

I nited states l IePartirent of Agriculture.

lorest Service.

Project No. ...-

Shipment

SHII'MENT IESCRHPTION.

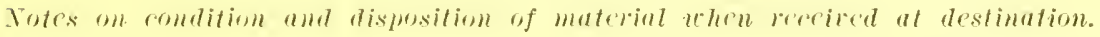

Receiverl at ( Nime of station.)

I iate

Condition whon received

IJow stored

liecolds :

Corresponslence

L'hotograplis

Care in descriptions essential.

The interpetation of experinental data very often dejends upon an accurate knowlerlge of the material used in the experiments. and no effort should be spared in making shipment descriptions as accurate and complete as possible.

\section{DESCRIPTION OF SAIMPLES.}

\section{Specimens for Laboratory collection.}

The Forest l'mulucts laboratory is building up a collection of authentic specimens of (1) crule or law materials, (2) intermediate prodnets forming a series which illustrate processes of manufacture, and (3) final products as put on the market. Slecimens are particularly desired of :

(1) Woods which have been identified botanically. Whenever possible, these spreimens shomld be taken from arerage merchantable trees and should inclube loth pith and lark in one piece. A section 1 foot or more in length is desiralile, but smaller pieces are arceltable.

(2) Simples of woml which have heen subjected to different processes. It is desimble to have a description of the processes to which the woot has been subjected, as woll as samples of the material used in its treatment.

(3) Samples of materials used in treating wood.

(t) Wrod distillation juenets.

(5) I'ulp, paper, and other filmer products.

In classes 3, 4, ama 5 a descripution of the process used in manufacturing the products shomld in all cases acommbung the samples.

(6) Samples of fungous growth ausing decay. A very complete description should accompany such suecimens, as otherwise they are of little value.

(7) Any rare, uncommon, or especially interesting simples of growth or changed jilysical structure of woot.

Description of Laboratory specimens.

The collector of any simple will fully describe it on sample form $r$. which is appended. and transmit the description with the simple to the director of the Forest I'poducts Liboratory, Mallison, Wis. The shipling tag on the sample will in all cases hear the name of the sender and the point and date of shimment.

On receipt at the laboratory the sample will be given a nmber, entered on the simple form d trinsmitted ly the collector. lieports on simples submitted for examination will hear the sample number and be filed with the sample description. All simples or specimens put into the permanent collection will bear the simple number. 
Forms for describing samples.

Simple form $d$.

\section{Ixited States Departalent of Agriculture.}

Forest SERTICE.

Project No.

Sample No.

SAMPLE் DESCRIPTION.

Class

Nilne of material

History of simple:

Growth conditions

(live features in detail. ${ }^{1}$ )

Manufacturing conditions

(Including short description of process. ${ }^{1}$ )

How ohtained

(1in dotail. if a portion of a shipment give the shipment number.)

Hy whom sellt

Dite sent

(Namo and address.)

How shipued

Remarks

Conditions at Laboratory:

Date of arrival _tation

condition in which recoived

Markis anul Iatbols

(liate on the packige.

How storel

'Trsted mater I'roject No.

Why sent

Worls to be done

Disposal of untised portions

Recorists:

Correspondence

(With dates.)

I'hotogrialis -

Iieports sulmuitter

(To whom, date, title, number of copies required.)

File

1 In case space is not sufficient, use sample form $a$ or sample form $b$ of shipment Deseription.

FORIM OF COOPERATIVE AGREEMENT.

Project No.

Title

\section{Inited States Department of Agriculture.}

Forest SERTICE.

Conprative agreement for iniestiyations in forest products.

Between of ment of Agriculture, party of the second yart. 
Wnereas the parties hereto desire to coolerate in conducting inrestigations

(State purpose and character of the investigations.)

Now, Therefore, THis Arreghent Witnessetil:

Finst. The party of the first part, for and in consicleration of the promises and agreements of the party of the second part, as hereinafter contained, does herehy promise and agree as follows:

(1) To pay to the C'hief, Othce of Accounts, Forest Service, Washington, D. C., to be placed to the credit of the Enited States, the sum of Too dollars $(\$+\ldots+--)$

Terms of payment, hy specified dates, ber month, rear, ote. When periodic payments are to be made, add "during the period that this agreement and all renewals thereof remain in force." When an additional eash deposit is reunired to insure the carrying out of the agleement. add " Forester upon the satisfactury completion of my (of our oblinations assumed luereunder:" )

(2) 'I'o furnish without chare to the Forest service the following timber, materials, apparatus, and libor, to be used in conducting salu investigatious:

(3) To relort, when refuested by the Forest Service, upon the application of the results attainel in sidid investigations.

(4) To pernit or refuire no laborer or mechanic employed on any work contemplated by this agreement to work more than eight hours in any one calendal day njon such work: if any laborer or mechanie is required or permitter to work more than eight hours as aforesaid. then to pay to the Thited States a pemalty of five dollars $(\$ 5.00)$ for each lahorer or mechanic for every allendar day in which such laburer or mechanie is required or pernitted to labor more than eight hours unon the work comtemplated hy this agreement, according to the provisions of the Act of Congress alproved June 19, 1912.

(Insert any adolitomal obligations ascumed by the cooperator.)

(5) That all moners pald mondre this agreement will, upon failure on his (or their) lat to fullill all and singular the comditions and requirements herein set forth or made a part heleof, he petained hy the United States, to be amplied as far as may be to the satisfaction of his (or their) obligations assumed helenmder.

'To deliver herewith. as a guarantee of faithful performance of the promises and agreements contained herein, a bond in the sum of _......... Too dollars $(\$---)$.

Skcoxd. The party of the second part, for and in consideration of the promises and agreements of the latry of the first pint, well and faithfully executed, does hereby promise and agree as follows:

(1) To

(Insert brief description of tests to be made or other obligations assumed

by Forest Service.)

(2) To report (Montlily, bimonthy, ete.)

to the party of the first part

the progress of the investigations conducted hereunder, and at the termination of said investigations to make a final and complete report on the results obtained, together with recommenditions.

(3) To pay any expense incurred by the party of the second part in conducting said investigations from the cooperative fund deposited with the United States for investigations in forest produets. (Or " from the appropriation by Cougress for 'General expenses, Forest Service,' 191-, Forest Products.") 
THund. If is mutually understood and agreed by and between the parties hereto as follows:

(1) That this agreement shall take effect on the day it is execnted by the party of the second part and shall expire on the thirticth day of June, one thousand nine hundred and ------, but the same shall be subject to renewal

thereafter from year to year. by mutual consent of the parties hereto, which renewal must be expressed in writing by said parties at least 15 days prior to the date of expiration.

(2) 'That the party of the second part shall lave unrestricted right to publish and distribute the results obtained flom said investigations in advance of their publication log the party of the first part.

(3) 'That all

(Apparatus, implements, materials, ete.)

furnished hy the party of the first part

and not consumed will gemain the property of said party when said investigations are terminated. All nuchines, implements, and materials furnislied by the Forest Service. and all specimens. samples. models, plans, drawings. negatives, and notes of manuscripts which have resulted from the investigations conducted herennder and which may he Gesired hy the party of the second part for record or jublication will be retained by said larty of the second part.

(4) That this agreement mas be terminated at any time by either party

hereto by giving - (specify number of days or month.) ether of such intention.

(5) That the decision of the Secretary of Agriculture will be final in the interpretation of the conditions and recpuirements of this agrement.

(i) 'That this asreement shall not be ascigned in whole or in part; that no Nember of or Delegate to Congress or Iosiolent Commissioner, after his election or appointment and either before or after he has qualified and during his continuance in office, and no officer, acent, or employee of the Goverument shall be admitted to ans sliare or jatrt of this contract or agreement, or to any benefit to arise theremon, and that no convict labor shall be employed in earrying ont the terms of this agleement, in accordance with Executive order signed May 18 , 1905. Nothing, however, herein contained shall he construm to extend to any incorporated company where such coutract or agreement is made for the general benefit of such incorporation or company. (Sec. 3741 , Revised statutes, and secs. 114-116, act of Mar. 4, 1909.)

In Witness WIIEREof the said party of the first part bas hereunto signed his mame on this the _..._... tay of _..._..., 19_.., anil the said party of the secend part has heremito set his hand on the date below written.

WTITNESSES :

(Name.)

(Title.)

Party of the first part. 10

Signed ly the party of the second part this (lily of

Fonester.

Party of the seconil part.

In agreements ajproved hy District Forester substitute " District Forester, District No. _..." for "Forester" in first elause and thereafter "District Forester." Similarly in agreements aplroverl by the Director of the Laboratory use "Director, Forest Products Laboratory" and "Director." 
In agreements alpuroved hy the Secretary, use "Secretary United states Department of Agriculture" in the first clause and thereafter " Secretary."

\section{Explanation of Agreement Form.}

The foregoing form can be used in all kinds of cooperative agreements by omitting clauses or phraseology inaplulicable and inserting. in the blanks indicated, slecial clauses required for a jarticular jroject.

\section{Deposits.}

All deposits under cooperative agreements will bo made with the Chief. Office of Aceomts. Washingtom. D. C. Allotments to the mit of the Franch conducting the work will be made in the regular mimmer, on green slips initiated by such unit and aplroved by the Assistant Forester in Charge of the Branch.

Guarantee on part of cooperator.

A special guaranty that the conerator will fulfill the oblimations assumed by him may be required in the form of:

(1) An additional caslo deprsit, to be refumded on the satisfactory completion of the agreement; or

(2) A bond.

In the first instance, a prorision for refunding such deposit will be inserted in Clanse (1). Part One, and the first part of ('la use (5). Part One, will be used. In the second instance, the second pilrt of Clause (5), Part One, will be used. Bonds slould be prepared on l'or'm $37 T$.

Such gnamanties will be requiled only in exceptional ases when neecssily to protect the Forest Service from serious loss ane to failne on the lint of the cooprelator to fulfill the obligations assumed under the agreement.

\section{Termination.}

All agreements terminate antomatically at the end of the current fiscal year, but may be renewerl. real by yeal, by mutnal consent. (Clause (1), Part 'Three). Termination at ofluer times may be providerl for, if alesimble in any specific case, by the use of Clause (4). Part Three. The mse of this elause and the perion of advance notice required will be optional with the executive ofticel in eharge of the broject. The Forest service will, however, resort to temination under this clanse only in exceptimal eases where the spirit or terms of the agreement have been seriously violated by the cooperator.

\section{STATION REPORTS.}

Men in charge of stations will be responsible for the preparation of Station Reports.

A record of materials on hame at the end of each month and of experimental materials used or treated during the month will be entered on the form "Material Received and 'Fester," and transmitted as a part of the station Report.

A statement of all expenses incurred at the station will be entered on the form. "Finaneial Report."

The body of the report will discuss the work done, treating each project separately.

The information contained in station reports will furnisln the basis for reports to cooperators in investigations conducted at the station. Reports to cooperators will be sent direct by the executive officer in charge of the unit conducting the project.

Station Report Forms.

\section{MoNTILY REPORT.}

\section{Name of Station.}

1 Progress of wolk auring montl.

(Inder this head aich project should be discusserl separately. Irojects should be described by number and title.)

2. Material received aud tested during month. 
3. Financial statement.

(If the expenditures cover more than one project, apportionment will be made and charger in the report to the lroper lroject. For example, if A received a salary of $\$ 10$ yer nonth and worked for half a month on Project No. 10 and the other half of the month on Project No. $30, \$ 50$ will be chirred to r'roject No. 10 and a similar amonnt to roject No. 30. The same method of apportioning the expenses will hold for other items. Cnder the colmm leaded "liemarls" will be given such statements as labor employed and charged om Form 1 or Form 4 or particular apparatus purchased or express and freight bills paid.)

4. General remarks and recommendations.

('This section should he devoter to a discussion of the effectiveness of working plans and recommended changes in them. Other matters of general interest should also be mentioned.)

\section{Material Received and Tested.}

Station,

Date, to inc.

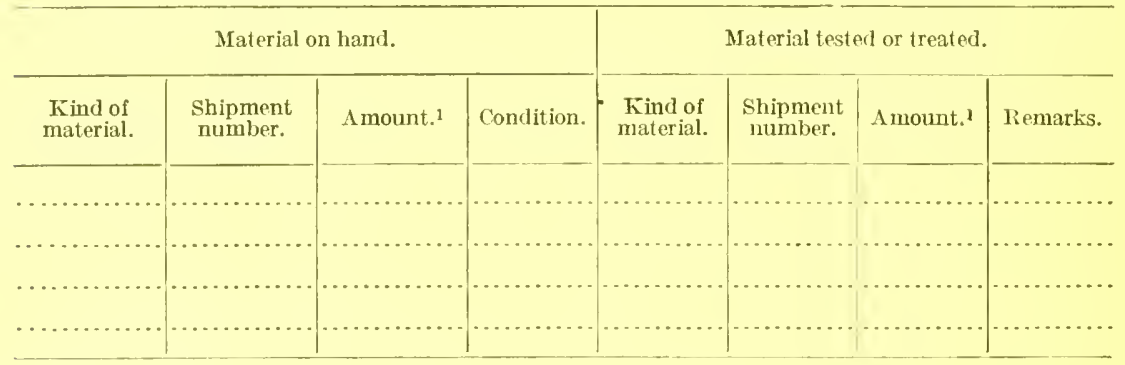

( Sigued)

In Charge of Station.

1May be in gallons, pounds, "pieces," "sticks," etc. State specifically.

FiNANCIAL REPORT.

Station,

Date.

to ine.

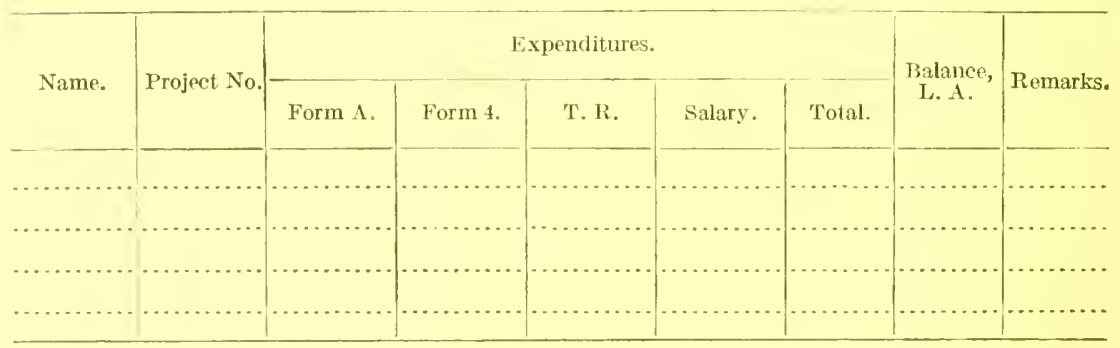

Approved :

In Charge of Station. 


\section{INBEX .}

Page.

Adlesses, approval of, before lelivery

Administrative assistants, l'orest I'roducts Laboratory

control action liv ussistunt forester-

Branch muits__._.

head of Brancl

investigations

in district ofliees-

relation to terbuical investigations.

under control of district forester

Advice exchanged by Laboratory and district oftices_._............. 12

Advisory board. Forest I'roducts Laboratory

Agreements. Afp Cooperative agrements.

Allotments, action to be takeu by assistant forester._._._.______ 14

Anmal investimative proslan, incorporation of technieal investigations in 24

Annual reports. Sece lieports.

Appentix

Aiticles, patented or proprietary, investigation of

Assignments for preparation of publications_______._.

of Laboratory stafif to district offices_._.

Foard, advisory, Forest I'roducts Laboratory

Branch units, administrative action by ...

Conmercial interests. publication of results affecting

plants, cooperition in construction of inspection of

Committees, Forest I'rerlucts Laboril tol'y

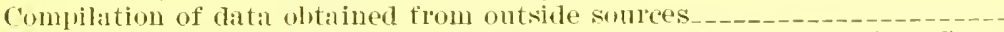
conferences between chief of Industrial luvestigations and district oflices.

Conferences between director of Liburatory and district oflices Conficlential informition _ Cooperation

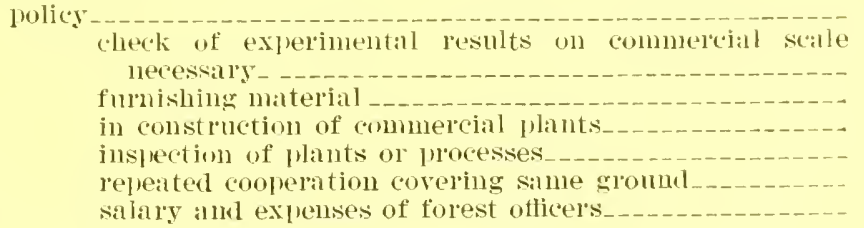

proceture

salary and expenses of forest officer's

agreements s apploval

alutherization

sllmmilry

whell in witing

Cooperative agreements, approval

deperits

explanition of

gualiantee by conolel'ator. preparation to be anthorized ..................

summary of procedure termination _._._._.

when acted upon by assistant forester........... when in writiug 
Correlation hetween different mits of Branch

Page.

Correspondence

genclial

arbons for other unitsis---

outsige of distriets -

how filed

Industrial lnvestigations _...

T:abol'i tol'y _.. _ _ n

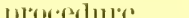

where referred

station

coplies of service correspondence

with ont sicle parties_____._.

Costs of details, apportionment of $\ldots$

testing materials, aplortionment of _...___- $1: 3$

Deposits under conerative arreements____.

Lescription of matelial leceived for experiments__ _ _ _ _ _ _. 2

simples.

slipments $29,3: 3$

Designs and prints, disjusil of _... 21

Totals, action to be tilken by asisistant forester.

from Laboliatory ol Industrial Investigations to astricts, costs of 13

birection of techuical work, Furest products Laboratory__________ 6

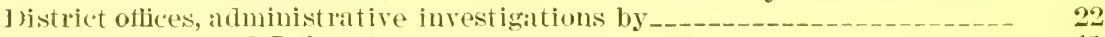
alnd Lilboriatory

aclministrative investigations _........ 11 confelences

current information and advice 12

special assiguments of Laboratory stafif _-_ 11

technical investigations._....... 11

tests of field material__._. 11

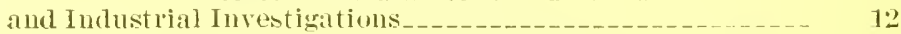

conferences._............. 12

tests of material

working plans _........... 12

ammual rejorts

costs of letails from Laboratory or Industrial Investigia-

tions. 13

inspections by members of

monthly reports_._.

National Forest utilization investigations _... 7

I'roducts experts in___._. 7

Divisions of Iirinch

Dolrability tests, insluertion reports on

juredure

נו10.

Eastern Forests, duties of Office of Industrial Investigations on _..._. 10

"Executive ofticer" defined.

Field notes _.

for'm fol

Field of lirimch work

libbolatory work _._.

Industrial Investigations work_

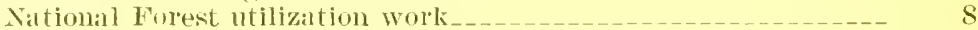

Files_.

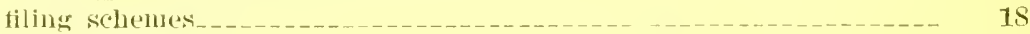

genelal chassification

correspomalence

information

moject records _.

test recolds

matters of general routine

Finincial report, station

Forest Products Laboratory. Sec Laboratory. 
Page.

Forest smpervisors, duties of

Form, cooperative agreement

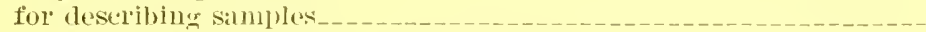

tield notes

notes at receiving station

on matmfatetming and shipling -

station financial repert monthly report

title-page of preliminatry report working blinl

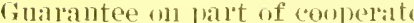
Imporements, Natiomal Forest, meservative treatment of material nsed in Intlustrial Investigations (oflice of )

and Liboratory

information

special tests

working plat1s._._.............

correspondence costs of letals to district oflices_______. duties on castern Forests field of work

in district oflices

insprections by members of . . . . n monthly rejuits ol anniziltion _._. jurjose

Information, classified, to be tiled confirlential

exchanged ly Laboratory and district offices._._._._._. fmrnished Laboratory by Inelustrial Investigations._._._._.

Iuspections, general by member's of district offices

Industrial Investigations _.........

Labolia tory -

Investigations, administrative, in district offices.

Forest I'roducts Laboratory

general, ontline of meliminary leport industrial

in district offices

liinds .

National Forest ntilization

of patented or promietary articles._._. of plants or processes, ontline for $\mathrm{r}^{2} \ldots$

terhnical__..___...

in distlict oflices

Iaboratory

administrative assistants.

advisol'y boal'd _. amnual reforts committees _........... compilation and publication of data from outside sources.--correspondence

costs of details to district oflices corrent information and advice to district offices. dijection of techuical work__. district oflices ald field of work Industrial Investientions and inspections by nembers of monthy rejorls _. organization _. linlpose sections _._. staff, assignment of members to district otlices 
Mannfacturers, tests by, of material from district foresters

Page.

Ianufiteturing, notes on

Manuscripts and addresses, aplyoval of

of publications, action on, by assistant forester-__.. 14

"Mark," shipment description, defined

Material, notes on, it recoiving siation______

patented or frofurietary, investimation of _ 20

received and tested, station lejort of

description of

sent Laboratery by districts for testing 11

industrial Investigations for tests by mannfacturers___. 12

Mouthly reports. Śe liejurts.

to be furnisher ly conjerator when practicable__._._._. 19

National Forest ulilization. S'e Utilization.

Notes. field

on manufacturing and shiping

on material at receiving station _.....

Oflice of Industrial Investigations and districe offices........ 12

Officel. sice Execut ive officel.

Oramization

allininistration head

divisions

Forest Products Laboratory

National forest Utilization.

Outline for preliminary l'eport

wolkillg flian__-_-

Patented alticles, materials, or processes, investifation of -

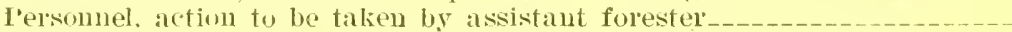

"I'iece," shipment description, defined.

Plans. See also Workine plans.

of wrik, actions to be taken by assistant forester

Plints ol plocesses, outline for investionatiou of

Policy, action on questions of. by assistant forester compilation of datil from outside sonrees in Laboratory lmblications comficleutial iufolmatioil disposal of prints and designsin cooperation _.

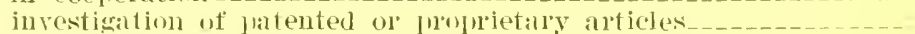
phblication of datal alfecting commercial interests__........... Preliminary reports, classified

for seneral investigations _._.

$f^{\prime}(r)$ investinations of plants or processes.

fol'm of tille-plage technical investigations,

juredine

plimpose

5

5

5

6

S

9

$\$ 1$

33

20

14

:3:

Preservative treatment of National Forest immovement material

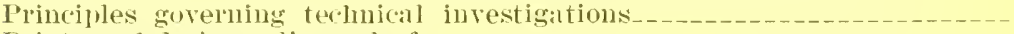
Prints and designs, disposal of

Procedure. Sce also lioutine frocedure, and technical procedure.

in cooleration

handing correspondence inspection reports on durability tests modifyin: allnoved working jilins. meliminary investigations mogress rejorts moject pepolts working jlans

Processes, commorcial, inspection of investigation of patented or lroprietary ontline for investigation of

Products Laboratory. Sce Laboratory. 
Page.

Progress reports,

natnre $\ldots \ldots 27$

procedure _...

Project records to be filed

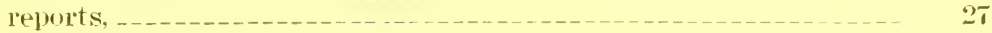

nature - 27

procedure - . 28

Projects, defined

desiguation of _.......

steps ill

Proprietary articles. materials, or processes, investigation of llanes, use of

Publication, aphroval of manuscripts and adllesses before... 2!) of data affectiur commeleial intelests._... 21 chtained from ontside sonleces_... 21

Publications, action on mimuscripts of, by assistant forester........ 14

l'urpose and orminnents for luepration of the Br:anch of

Forest Products Laboritory

National Forest ntilization inestigations...............

lndustrial Investigations _...

Recorts. Nee Files.

liemuneration by conpritor of costs to Service-1 19

Reports, attion oll, by assistant forester. anmual

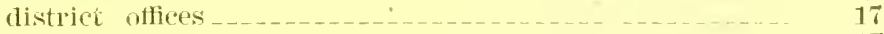

Labolitol'y _. 17

financial, station

inspection, on durability tests__..... 27

monthly_...

district offices

Inciustrial Investigations ___ 17

Labolatory _............

statioll

preliminary _...... 30

mogress_...

jroject _.

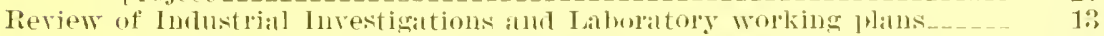

proposed technical investinations___._. 24

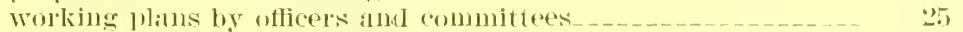

Rontine mocelure. administrative control action by assistant forester... 14

Branch units.... 14

ammual reports

listrict oftices .

Laboratory. 17

correspondence _.......

general _.

Industrial Imvest imatioms.

Ialboratory_

repluests for juformation 15

station _........... 16

files_.

filing schelles.

genelal classification _.

mattel's of genelal routim 18

monthly relorts

district offices _._. 16

Industrial Investigations......... 17

Laboliatory

station 16

Simples, defined

description of
for Jaboratory eollection

form $\mathrm{fol}$

Scientific work of Franch, direction of 
Seople of Branch work

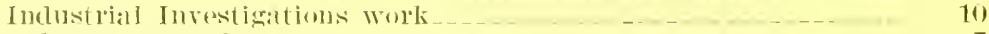

Laboratory work

Natiomal Forest ntilization work _...... S

working flans for teebuical investigations

Serdions, Lalhoratory

Shipment, definerl _..

descriptions.

(all ressential _...__ _...

fielll botes _. 33

form fol $\ldots$. 34

"matk" defings _... 33

notes at receiving stallon

f(1)' for

notes on manufacturing and shipjing 34

fol'm fol 1 . $\quad 34$

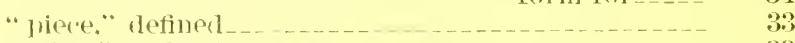

"stick," definerl _..._. 33

Sluipling, notes on__._.

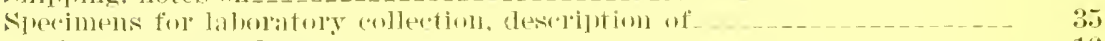

Station. сотrespondence

rejmis, finilncial

monthly

formis of

on material peceived and testrel

Stations -

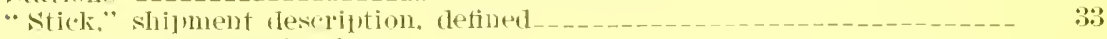

Stulles. Sre Investigations.
sumelisors, duties of of

Teelunical investigations _.

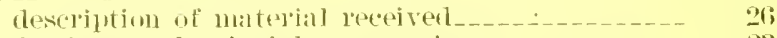

fund:mental forincinles surerning _._.

incolporation in anmul investinative prosram $\quad 24$

jn district whices

inspection repolpt om durability tests_______ 27

jueliminaly _.

mongess re]mits _._.

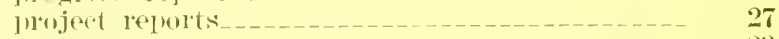

lilojecrom

Working flills _.

procedme andustrative investigations

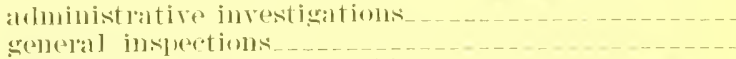

illspertion reforts on dumbilily lests.....

linds of investimations._.

lullit;itions _.

teronicanl investigntions

work of Branch, direction of _..... 6

Termination of coolerative agreements_. 89

Test costs, almertionment ot

recoris to fer filed

'Jests loy Labolatory of material from distriet foresters _ 11

Imlustrial luvestimations. 13

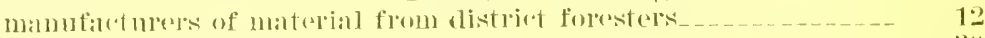

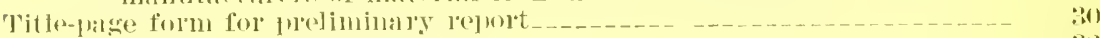

Wolking lilill

Tilization, National Forest

alin of investigations

field of wirk

low investigited

oreanization

preservative treatment of materials neel in

imporements 9

purpose 
Work of Branch, actions oll plans of. hr assistant forestel

Page. preference to National ropest prohlems

scope of

Laboratory - - - - - -

Working plaus, approval

for Industrial Investigations, reviewed by Iaboratory for statistical and industrial stmdies in district offices

for technical investimations in districts

form of title-page

imprortince

outline

frocednre - _.

with modifications _____-

review by oflicers and ammmittex

scope- 




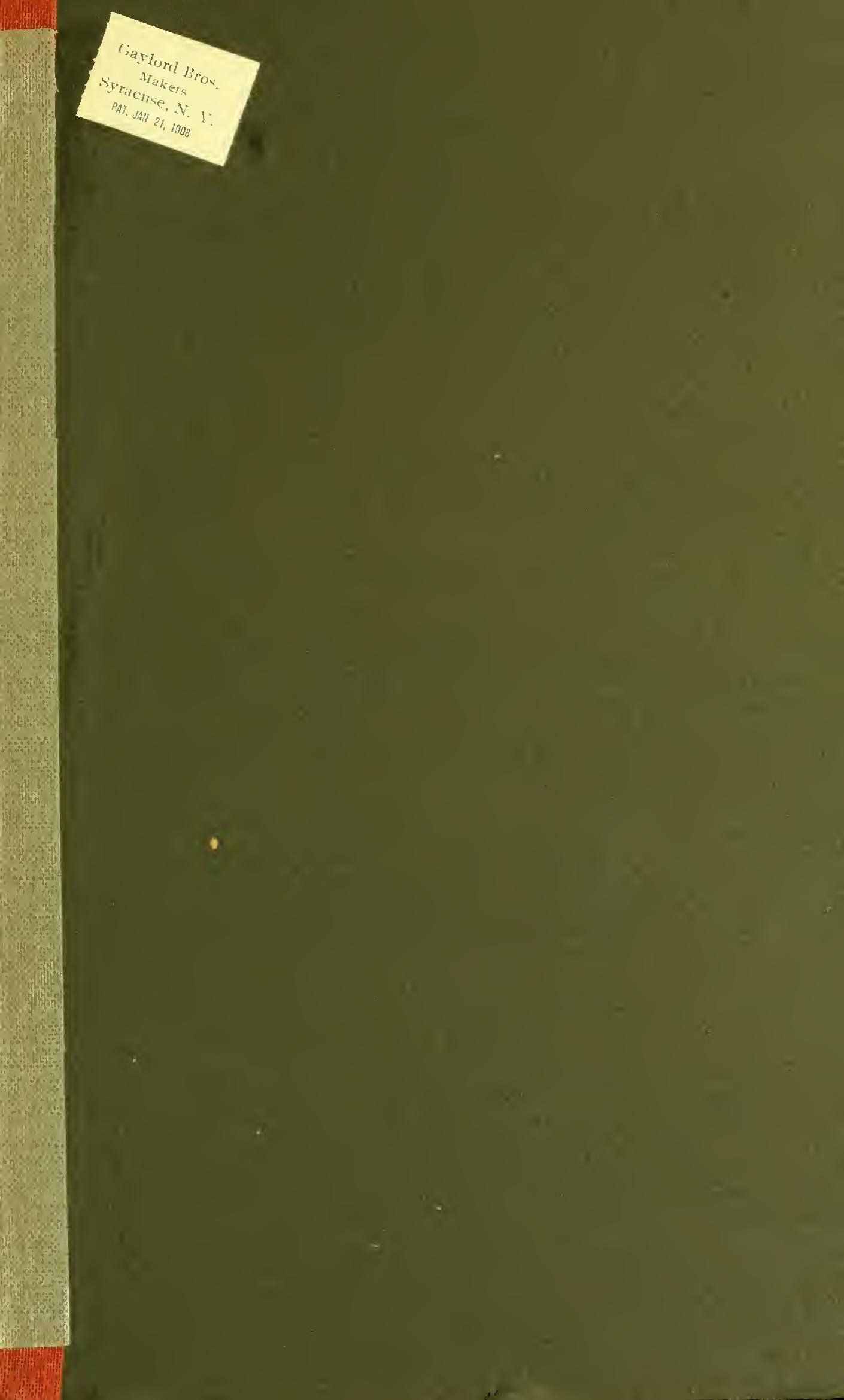


LIBRARY OF CONGRESS

00032340234 